\title{
Spatial Layers and Spatial Structure in Central and Eastern Europe
}

\author{
Zoltán Egri This paper analyses the special features that \\ Szent István University characterise the spatial structure of Central and \\ E-mail: Eastern Europe, a region still in the phase of \\ egrized@gmail.com transformation. This topic has already been \\ discussed by numerous authors (Gorzelak 1997, \\ Rechnitzer et al. 2008); the corresponding studies \\ have identified both greater and lesser developed \\ Tamás Tánczos \\ Eszterházy Károly University \\ E-mail: \\ tanczos.tamás@ektf.hu \\ Keywords: \\ Central and Eastern Europe, \\ spatial layers, \\ spatial structure, \\ spatial autocorrelation \\ areas, as well as other intermediate areas, leading \\ to various 'geodesigns', figures, and models. First, \\ a brief description of the main studies of spatial \\ structure affecting the macroregion is given; then \\ our definition of the spatial structure of Central \\ and Eastern Europe is outlined. This is not only \\ based on the main traditional development \\ indicators (e.g. GDP per capita, unemployment \\ rate, and business density), but also considers the \\ spatial structure layers (economy, society, \\ concentration, settlement pattern, network, and \\ innovation).
}

\section{Introduction - Spatial structure in Central and Eastern Europe}

Many spatial structure figures and models have already been developed to describe the macroregion of Central and Eastern Europe, mostly on the basis and under the influence of Western European territorial concepts (Brunet 1989, EC 1999, Hall 1992). In terms of socio-economic development, the most successful and well-known core area is named as 'Eastern European' or the 'red banana' (or 'boomerang') (Cséfalvay 1999, Gorzelak 1997, 2001, 2006, Rechnitzer et al. 2008). According to the authors, the near-uninterrupted zone of development is formed by city regions, including, in particular, Budapest, Vienna, Bratislava, Brno, Prague, Poznan, Wroclav, and Gdansk. The banana model also demonstrates the future development zones: one includes Berlin and Leipzig with the Warsaw axis, while the other comprises the Adriatic region (Slovenia and Croatia) and the southern and eastern provinces of Austria. In addition, there are temporary regions (e.g. industrial districts and tourism zones) and peripheral 
rural areas, such as the eastern wall at the bottom of the development slope. The success of the banana model is clearly demonstrated by the appearance of its revised version, i.e. the 'new banana' (SIC! 2006). The main feature of the region is PanEuropean Corridor IV: this is the axis along which we find the countries and regions under review, which has the 'potential for the second economic core area within the EU'. Compared to the concept developed by Gorzelak, the new banana takes a 180-degree 'turn' towards the west with the addition of Slovenia and the regions of (the former) East Germany. Although the development direction heads towards Warsaw, its starting point is not Berlin but the Brno-Warsaw transport axis which also crosses Silesia. The Western European polygon concepts (Hall 1997, ESDP 1999) have also left their mark in the region in the form of a pentagon. The main cornerstones, or gravitation zones, of the Central European pentagon are Berlin, Prague, Vienna, Budapest, and Warsaw; in fact, a similar concentration is seen in the region surrounded by these cities, as in the case of the 'big brother' (Egri-Litauszky 2012). ${ }^{1}$ The polycentric spatial concept ('bunch of grapes', Kunzmann-Wegener 1991) arrived in the form of $\mathrm{MEGA}^{2}$ regions where the actual 'grapes' (capital cities and large cities) fall into potential and weak categories ${ }^{3}$ only.

When examining the spatial structure of the region in comparison to Western European regions, we should not ignore the fact that Central and Eastern Europe can be considered only as a periphery since the economic field of force is almost entirely dominated by wider European impacts (Nemes-Nagy-Tagai 2009, Kincses-NagyTóth 2013). Although it appears in many figures of the European spatial structure mostly as a target direction, or part of a corridor, or as an attachment to more developed regions ${ }^{4}$ - the region cannot be verified as having a major independent spatial structure form, at least according to our sources that also feature methodological components (Kincses-Nagy-Tóth 2013a, 2013b).

\section{Spatial structure analyses}

In his in-depth study providing a systematic approach to spatial structure figures, Szabó (2009) describes the main directions in the research and processing work of this topic. Spatial structure research can be categorised according to geographical and regionalist aspects. According to advocates of the former approach, the elements of geographical environment (region types) and the networks (e.g. settlements and infrastructure) qualify as spatial structure units used for the representation of socio-

\footnotetext{
${ }^{1}$ The main spatial structure models can be seen in the Annex.

2 Metropolitan Growth Areas.

3 See EC 2007 for details.

${ }^{4}$ As in the case of, e.g., the 'Red Octopus' (Van Der Meer 1998), the 'Blue Star' (Dommergues 1992) or global and European integration zones (ESPON 2007a).
}

Regional Statistics, Vol 5, No 2. 2015: 34-61; DOI: 10.15196/RS05203 
economic weights. Conversely, the regionalists study territorial inequalities and describe spatial structure in terms of qualitative and quantitative differences. According to Szabó, it is also permissible to combine the two approaches. Representing one of the trends of spatial structure research approaches, Rechnitzer (2013) also discusses - commencing with the main indicators (e.g. GDP per capita) the identification of territorial inequalities and the delineation of development types; and then are subsequently refined in view of further information. The other trend is a combined (multivariate and/or simulation) assessment method based on the various layers (economy, society, settlement network, geographic, environmental, etc.) of the territorial units.

Turning to our objectives, this paper essentially follows the regionalist approach, but we wish to interpret and describe the spatial structure layers and then to create a compound spatial image for Central and Eastern Europe. In our opinion, this topic has not been considered to date using this type of mathematical-statistical approach. It should be noted that our study is not intended to serve developmental purposes. Instead, it is targeted towards initial exploration.

\section{Issues of research methodology}

Our spatial structure analysis was carried out in six steps. Accordingly, the study describes our research logics, main considerations, and work methodology (e.g. territorial level and database).

1. Our first step was to perform the operationalisation of spatial structure layers (i.e. the studied phenomena) $)^{5}$ and to explore the phenomena attached to the individual layers. We defined the layers in view of the challenges and transformation phenomena at global and European levels and near-consistently with the major studies concerning spatial structure (Gorzelak 1997, Leibenath et al. 2007, SIC! 2007, Rechnitzer-Smahó 2011, TA 2011, ESPON 2014, Simai 2014, SzabóFarkas 2014, etc.).

- The layers of economy and society remain displayed as central categories. The former layer is studied in terms of its static, dynamic, and structural features. The latter layer has been redefined: the phenomena of demographic transition (EC 2014, ESPON 2014, Simai 2014) and territorial social cohesion (EC 2008, ESPON 2014) have become the subjects of the society layer.

- As the process of globalisation has reinforced the economic role of territorial concentrations (EC 1999, Lengyel 2003, TA 2011, Lux 2012),

${ }^{5}$ The layer structure is mentioned by Rechnitzer-Smahó (2011), but there are no detailed guidelines in literature sources for the complex mathematical/statistical approach to this issue. In our opinion, the notion of layers is best approached through the theory regional capital and competitiveness (Stimson et al. 2011, Lengyel 2012).

Regional Statistics, Vol 5, No 2. 2015: 34-61; DOI: 10.15196/RS05203 
concentration is defined as a separate layer centred on the density of population, labour force, and economic output.

- The layer of settlement pattern has been included in the study to highlight the growing level of urbanisation (TA 2011, ESPON 2014). Although the layer of concentration presumably supplies some information on the development poles, we need to also gain insight into their expansion and agglomeration. This layer is examined in terms of the use of space (ESPON 2006).

- The network, layer is accepted as described by Rechnitzer-Smahó (2011) and examined for the aspects of infrastructure and settlement.

- The importance of knowledge - as the 'only meaningful resource'

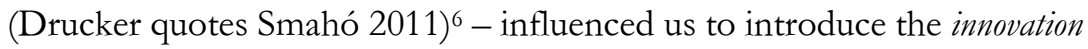
layer, which plays an increasingly important role in regional growth, development, and competitiveness (Smahó 2011, OECD 2013).

- Due to the socio-economic nature of our analysis, we decided not to include the geographic, environmental and institutional layers (e.g. public policies and regulatory system) mentioned by Rechnitzer-Smahó (2011) (see Figure 1).

2. We loaded the spatial structure layers with a sufficient volume of relevant data. We determined the relevance and suitability of the data based on numerous literature sources and research reports dealing with this topic; we then created a database.

3. We used R type factor analysis to identify correlations of the loaded information by layer (Sajtos-Mitev 2007). In particular, we used main component analysis and attempted to create an independent principle component (of adequate statistical parameters 7 ) for each layer. This method provides an opportunity for weighting and differentiating the importance of variables (Kovács-Lukovics 2011).

4. Mapping the main correlations of the spatial structure layers. For technical and statistical reasons, it is desirable to examine the relationship between layers. Accordingly, we have performed correlation analysis (Pearson-Spearman) and Kaiser-Meyer-Olkin (KMO) measure of sampling adequacy index calculation, as well as bivariate global and local autocorrelation analyses. ${ }^{8}$ The correlation and spatial autocorrelation analyses identify any coherence/incoherence between layers and indicate how and where the layers strengthen or weaken each other. The results of the KMO index calculation demonstrate the aggregate redundancy of the spatial structure layers.

${ }^{6}$ Knowledge is approached along the lines of knowledge economy, the centre of which is knowledge creation, and this is what innovation means in our opinion.

${ }^{7}$ The communalities must be above 0.25 , the eigenvalues must exceed one, the proportion of retained variance must be higher than 60 percent, and the KMO value of the indicator structure must be at least in the acceptable category. (See Sajtos-Mitev 2007 for details.)

${ }^{8}$ It belongs to the tool set of explanatory spatial data analysis (Anselin 2005, Tóth 2013).

Regional Statistics, Vol 5, No 2. 2015: 34-61; DOI: 10.15196/RS05203 
5. Through assignment into homogeneous groups and mapping, it is possible to identify subregions with similar characteristics and to subject them to spatial analysis. In view of its numerous advantages (applicability, interpretation, etc.), two-step cluster analysis was used. The resulting clusters were mapped. The homogeneous groups were interpreted according to three types: cities/urban areas, agglomerations, and rural/peripheral areas.

6. As the subregions involved in the analysis had been created in different manners (size and population), we applied amendments and corrections. This was done by mapping the settlement network features and thus supplementing the network layer.

Figure 1

Spatial structure layers for Rechnitzer-Smahó (2011) and the new model

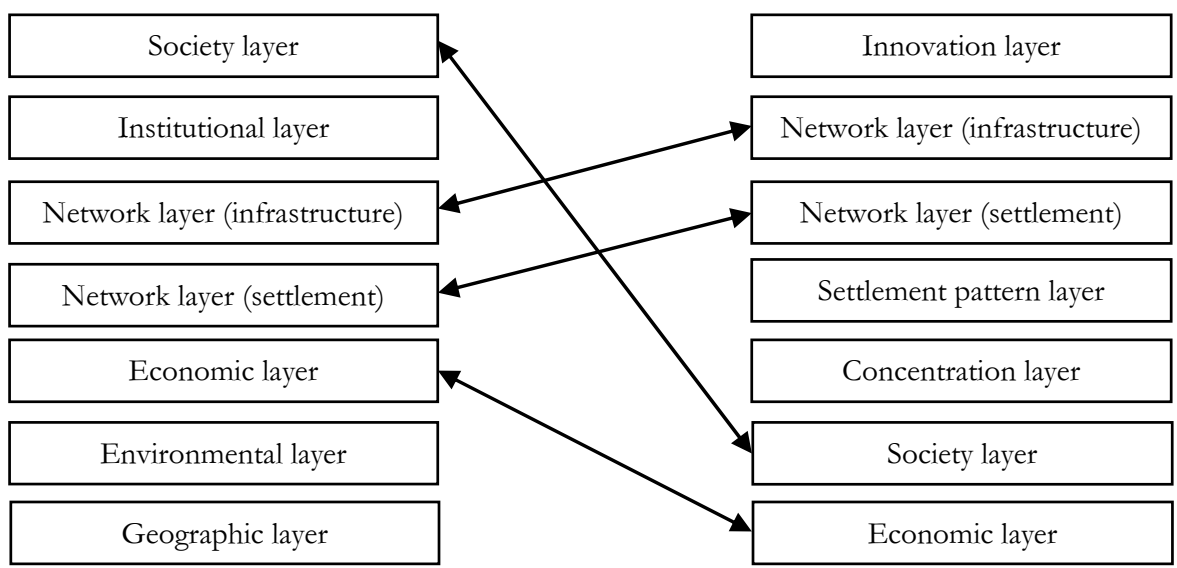

SPSS for Windows 20.0, GeoDa 16.6, and ArcGIS 10.2 software products were used for the implementation of our research tasks.

\section{Territorial delimitation}

At macro-level, the following countries provide the spatial framework for our study: the Visegrád Four, Slovenia, Romania, Bulgaria, (the former) East Germany, and Austria. We considered it important to also involve the former East German region for two reasons: first, the spatial structure figures of Central and Eastern Europe include the region (even if not as an integral part); second, it is still considered a region in transition (Paqué 2009, Horváth 2013). Absent sufficient data, we had to ignore Croatia and other countries of the Balkans. NUTS3 subregions were selected to act as a spatial framework at meso-level. The advantages of using this level include the possibility of more detailed 'construction', great similarity to the actual spatial structure, little (or at least lower) loss of aggregation information, and a high number 
of components; furthermore it can be viewed as the level of regional decentralisation in most of the countries involved (Tóth 2003). The numerous disadvantages include the limited database (although there are promising initiatives, e.g. ESPON 2005, 2012a, 2012b), GDP reliability concerns (Dusek-Kiss 2008), and high levels of deviation for the populations. ${ }^{9}$ The issue of modifiable territorial units represents a natural disadvantage, while the area delimitation (Dusek 2004) produces strong implications for the study. Within the area under review, for example, (the former) East Germany has 26 cities qualifying as NUTS3 units, while the Czech Republic and Hungary have only one such city each.

\section{Database}

At the time of creating our database, efforts were made to load each layer with relevant data of adequate quantity and quality. As a first step, we reviewed the literature sources and research reports dealing with this topic and region (ESPON 2006, Dijkstra 2009, ESPON 2007a, 2007b, 2010, EC 2010, Dijkstra-Poelman 2011, ESPON 2012a, 2012b, 2014). The reports are coupled with online databases; the European Observation Network for Territorial Development and Cohesion (ESPON) and the sources of Eurostat offered a solid basis for loading each layer with data. We have downloaded or created a total of 47 specific indicators. The observation period included the final years of the first decade of the 2000s (2006-2010). Unfortunately, some indicators (e.g. accessibility and use of space) were available only for a single year, and certain regions of the NUTS system underwent border changes, which prevented us from making any assessments post-2010. The selection of variables for the spatial structure layers was carried out through main component analysis, the results of which are shown in Table 1 below. The principal components are figured on boxplot maps (Figure 1).

\section{Results}

Economic layer. The sole main component indicates clear correlations. Higher economic output (gross domestic product, GDP) is positively correlated with services, business, industrial output, and tourism capacities, while agricultural employment and economic growth are negatively correlated with the former indicators. The contradiction in the polarity of the correlations between the static and dynamic variables of the economy shows the process of convergence in the region. The boxplot map indicates marked and general territorial differences, but there is no outstanding value in the component value of the economy layer. There is a clear eastwest split between the continuous regions of high and low development levels.

${ }^{9}$ The relative deviation of population is $90 \%$ in the region under review.

Regional Statistics, Vol 5, No 2. 2015: 34-61; DOI: 10.15196/RS05203 
Almost the entire area of Austria is shown in the (most developed) upper quartile, accompanied by each of the East German cities and their agglomerations. Warsaw, Prague, Budapest, and Ljubljana are also in this group. The economically peripheral areas cover almost the entire area of Romania and Bulgaria, and only a few regions with one or two cities and tourism districts (e.g. Timisoara, Cluj Napoca, Varna, and Constanta, as well as Bucharest and Sofia with their agglomerations) are excluded from this region type. Moreover, the (less developed) lower quartile covers most of Poland; excluded are the former Prussian regions, the Silesian core area, and the cities with their hinterlands. Within the new EU member states, only the surroundings of Prague (a former Bohemian area) and Ljubljana display the typical concentration of subregions representing the (above average) third quartile, while in other countries the same is shown only by single cities. None of this type can be found in Hungary, which is a sign of excessive concentration.

Table 1

Indicators of the principal component analysis by layer

\begin{tabular}{l|r}
\hline Layers & Component \\
\hline Economy (KMO: 647; total var: 65.70\%; eigenvalue: 5.25) & \\
\hline Gross domestic product per capita (PPS), 2009 & .915 \\
Gross value added per capita (euro), 2009 & .947 \\
annual work unit in agriculture, 2008 & -.809 \\
industry gross value added per capita (euro), 2009 & .725 \\
service sector employment share, 2008 & .864 \\
financial services and real estate market employment share, 2008 & .850 \\
commercial accommodation/1000 persons, 2008 & .601 \\
cumulated economic growth (\%), 2006-2010 & -.716 \\
\hline Society (KMO: 693; total var: 59.35\%; eigenvalue: 2.97) & .748 \\
\hline population, 2010 (logarithmic) & .827 \\
population change (\%), 2006-2010 & .731 \\
net migration (\%), 2006-2010 & -.657 \\
unemployment rate as a share of active population, 2008 & -.871 \\
\hline ageing index, 2009 & \\
\hline Concentration (KMO: 851; total var: 78.28\%; eigenvalue: 3.91) & .977 \\
\hline economic density (GDP/km²), 2009 & .980 \\
employment density (employed persons/km²), 2009 & .968 \\
population density (person/km²), 2009 & .883 \\
territorial productivity (GDP/built-up area), 2008 & .954 \\
\hline Network (infrastructure) (KMO: 647; total var: 81.68; eigenvalue: 2.45) & \\
\hline accessibility by rail (\% of EU27 average), 2006 & .791 \\
accessibility by air (\% of EU27 average), 2006 & \\
accessibility by road (\% of EU27 average), 2006 & \\
& \\
\hline
\end{tabular}

Regional Statistics, Vol 5, No 2. 2015: 34-61; DOI: 10.15196/RS05203 


\begin{tabular}{l|c}
\hline Layers & Component \\
\hline Settlement pattern (KMO: 802; total var: 72.52\%; eigenvalue: 3.63) & \\
\hline share of non-continuous settlement pattern, 2006 & .968 \\
share of urban tissue, 2006 & .967 \\
share of artificial surfaces, 2006 & .960 \\
settlement density (share of built-up and agricultural areas per capita), 2006 & -.695 \\
population potential (share of population within 50 km radius), 2008 & .591 \\
\hline Innovationa) (KMO: 710; total var: 89.25\%; eigenvalue: 2.68) & \\
\hline share of patents filed at EPO & .910 \\
share of high tech patents filed at EPO (patents/million persons), 2006-2009 & .952 \\
share of ICT patents filed at EPO (patents/million persons), 2006-2009 & .971
\end{tabular}

a) Regarding the database, we adhere to the trend represented by Porter-Stern (2003), i.e. innovations are identified with patent data. This idea has been widely criticised (e.g. Bajmócy-Szakálné 2009, OECD 2011). However, according to Varga (2009), patents represent fairly reliable measurement tools for innovations.

b) European Patent Office.

Source: Eurostat, ESPON online databases, own calculation.

Society layer. According to the main correlations, subregions with a higher ageing index have higher than average unemployment rates. Moreover, areas with a high rate of natural reproduction show high population numbers and high net migration rates. The parameters of the main component analysis can be considered adequate. The lower quartile accommodates mostly East German subregions, a few Bulgarian subregions, and one Hungarian subregion; the high levels of ageing, population decline, and unemployment jeopardise the social cohesion of the region here. The society layer is below the average in almost all East German regions: only three (Berlin, Dresden, and Potsdam) of the 103 NUTS3 regions indicate higher than average values. The ageing index is by far the highest here: the average is 232 percent, while the city of Hoyerswerda provides the extreme value ( 357 percent). The positive processes of retaining a stable population size indicate a split also at country level: Poland, the Czech Republic, Slovakia, and Slovenia (with very few exceptions) perform continuously above the average. This layer also shows urban-rural differences which are typical mostly in Austria, Hungary, Bulgaria, and (the former) East Germany.

Regional Statistics, Vol 5, No 2. 2015: 34-61; DOI: 10.15196/RS05203 
The spatial features of the layers in Central and Eastern Europe

Figure1
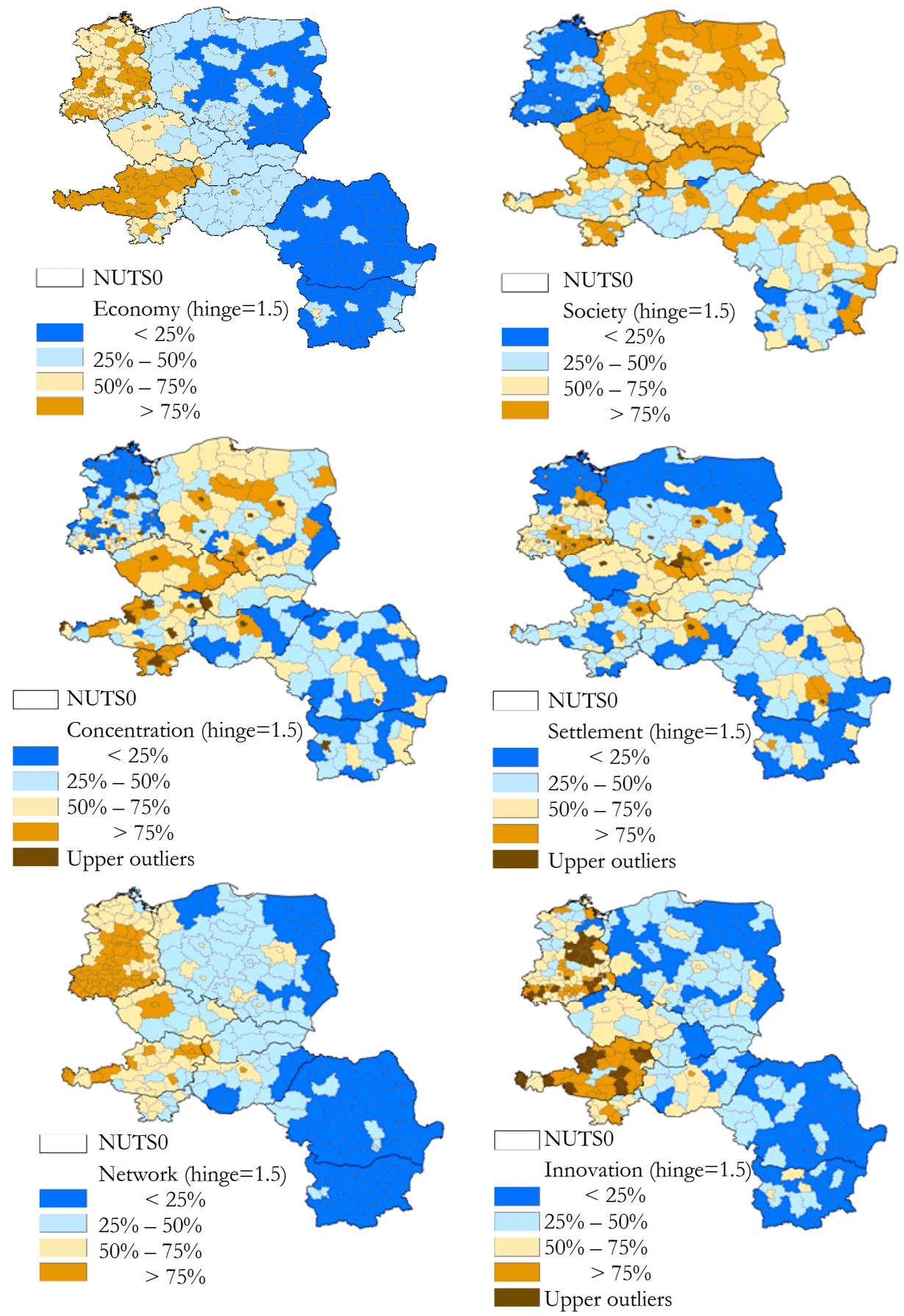

Regional Statistics, Vol 5, No 2. 2015: 34-61; DOI: 10.15196/RS05203 
Concentration layer. The indicators of socio-economic nodes show positive and significant correlations: economic output, population, labour force, and territorial efficiency rates are concentrated in a main component of desirable characteristics. Due to the special features of territorial delimitation, the cities (e.g. Berlin, Budapest, Vienna, Cracow, Szczecin, etc.) or the subregions with small agglomerations (e.g. Bratislava, Salzburg und Umbegung, Graz, and Osrednjeslovenska ${ }^{10}$ ) - acting as places that accommodate socio-economic concentrations - enjoy natural advantages. For statistical purposes, most of these cities (37) are outliers: they dominate the Central and Eastern European area. Their concentration is outstanding: the 37 regions cover $1.8 \%$ of the area under review, yet $20 \%$ of the population and $26 \%$ of the employed people are concentrated here, and more than $35 \%$ of the GDP is produced. The concentration layer ranking is led by Bucharest, Vienna, Warsaw, Budapest, Berlin, and Prague, followed by the large Polish centres (Cracow, Poznan, Lodz, Wroclaw, and Katowice) and then by the cities of Germany, Austria, Slovenia and Bulgaria. It should also be noted that the territorial delimitation does not always help certain subregions, as some smaller German cities (of 40,000-100,000 inhabitants) are not among the outliers (e.g. Frankfurt, Görlitz, Plauen, Cottbus, Eisenach, etc.). Nevertheless, in the case of these cities we can also see the 'formation' of wider agglomerations, the components of which are found in the fourth (top) quartile. These include, for example, the cross-border region of Upper Silesia, Pest county, and Jihomoravský kraj with Brno ${ }^{11}$. It is also clear that there is no uniform range for certain large centres; this is particularly evident in the case of Berlin. In less polycentric countries, the subregions can be identified only based on output shown in the third quartile. This category (i.e. lower socio-economic gravity points) includes, among others, the Szeged and Györ subregions in Hungary, Temes, Cluj, Constanta, Brasov, and Iasi counties in Romania, and Plovdiv, Burgas, and Varna in Bulgaria. Regarding Hungary, the western counties in the third quartile also indicate the direction of attachment to more developed European areas. The scarcely populated peripheries are located mostly in the northern part of (the former) East Germany, along the Carpathian Mountains, in East Poland, and in the rural areas of Bulgaria and Hungary.

Network layer. The weight of accessibility by road and rail is higher in the main component, while the weight of accessibility by air is less pronounced (given that airports occur 'less frequently' in the area), but it is still rather strong. All three indicators of accessibility are positively correlated and reinforce each other. The boxplot map shows normal distribution for the main component; there are no regions with outstanding values and the figure displays the centre-periphery features of transport geography. The developed continuous core of the network layer is provided by East German subregions. Regions in the fourth quartile - containing Austrian and German

${ }^{10}$ Central Slovenia, i.e. the subregion of Ljubljana and its agglomeration.

${ }^{11}$ South Moravia region.

Regional Statistics, Vol 5, No 2. 2015: 34-61; DOI: 10.15196/RS05203 
subregions, as well as the agglomerations of Budapest, Bratislava, and Prague - exceed the EU average for all three indicators. As regards the Czech Republic, Slovakia, and Hungary, subregions of higher value can be seen only along Pan-European Corridor IV (showing the way stations, e.g. Budapest, Wien, Berlin, etc.), which indicates the region's directions of western attachment and the backbone of the potential economic core area. The north-western part and some large cities of Poland represent accessibility nodes; the former benefits from the vicinity of Germany, while the latter enjoy an advantage from the presence of airports in the regional subcentres. This accessibility feature represents a justification for the new banana. In the members of the lower quartile - covering, among others, the Polish eastern wall according to Gorzelak, most subregions of Romania and Bulgaria, and the peripheral areas of Hungary - the rates of accessibility by rail, road, and air are approximately onequarter, below one-third and slightly above two-fifths of the EU average respectively.

Innovation layer. The indicators making up the layer that expresses innovative ability (and knowledge economy) display relatively strong positive correlations. The spatial analysis indicates the emergence of dynamic agglomeration benefits in the region (Lengyel-Rechnitzer 2004), but with a strict east-west division line. Jena, Vienna, Berlin, Graz, Salzburg, Linz, Wels, Dresden, Greifswald, Ilm kreis, Leipzig, Frankfurt, Potsdam, Erfurt, and their agglomerations have a clear dominance over the Central and Eastern European area. These subregions (36) are outliers; this fact is evident from the concentration of the indicators involved. This area produces $60 \%$ of all patents, $70 \%$ of high tech patents, and $67 \%$ of ICT patents. Sitting in the fourth quartile, Budapest ranks highest in this regard among the Visegrád and Balkan subregions, while Prague, Warsaw, Bucharest, and Sofia are only in the third quartile. The concentration of patents displayed by the below-average groups provides information on the uneven distribution of innovation output. It is below 1 percent in the first quartile and, even if the first and second quartiles are combined, the total is still below 5 percent for all three patent forms.

Settlement pattern. The analysis has revealed clear correlations: the indicators regarding urban use of space and the share of population within a $50 \mathrm{~km}$ radius are positively correlated, while the share of built-up and agricultural areas per capita is inversely correlated with the component. The statistical tests used for suitability verification show compliance. The spatial analysis of the main component results in a more marked display of the cities and their emanating impacts (agglomerations), and the rural areas are also delimited. Urban agglomerations are shown by the 32 cities (outliers) and the related upper quartile. The main settlement structure nodes are represented by Berlin, the continuous zone of Dresden, Chemnitz-Zwickau, Leipzig, Halle and Magdeburg, Upper Silesia centred around Katowice and the agglomerations of Warsaw, Lodz, Prague, Vienna, Budapest, and Bucharest. Based on indicators regarding the use of space, the rural areas are also exhibited with their typical features, and it is easy to identify the German-Polish Plain as well as the rural areas of the Czech Republic, Hungary, Romania, Bulgaria, and Austria.

Regional Statistics, Vol 5, No 2. 2015: 34-61; DOI: 10.15196/RS05203 


\section{Main correlations of the spatial structure layers}

According to Rechnitzer (2013), the various layers are placed on top of each other in space. Their impact and strength may vary at the individual spatial points, with the layers reinforcing or destroying each other. Layer correlation is first examined with the Pearson and Spearman correlation coefficients ${ }^{12}$ (Table 2). The correlation of individual layers generates mostly significant results, although a diverse picture emerges according to their strength. Based on the Pearson correlation coefficient, the strongest reinforcing correlation exists between the network and economy layers and between the concentration and settlement structure layers. The interpretation of these (synergistic) relations can be fine-tuned by the rank-order correlation coefficient, as it gives further information on the relationship between the network and innovation layers and between the innovation and economy layers. Synergistic relations of medium strength exist between the innovation and settlement structure layers, society and concentration layers, settlement structure and economy layers, concentration and economy layers, and innovation and concentration layers. It is interesting to see the weak inconsistency and antagonistic impact between the society and economy layers, indicating a serious spatial split of the two most important phenomena in Central and Eastern Europe. According to our calculations, there is no significant interaction between the society and settlement structure layers.

Main correlations between individual layers based

Table 2 on the Pearson and Spearman rank-order correlation

\begin{tabular}{l|r|r|r|r|r|r}
\hline & Economy & Society & $\begin{array}{c}\text { Concent- } \\
\text { ration }\end{array}$ & $\begin{array}{c}\text { Infra- } \\
\text { structure }\end{array}$ & Innovation & $\begin{array}{c}\text { Settlement } \\
\text { pattern }\end{array}$ \\
\hline Economy & 1.000 & $-.263^{* *}$ & $.358^{* *}$ & $.873^{* *}$ & $.558^{* *}$ & $.462^{* *}$ \\
Society & $-.259^{* *}$ & 1.000 & $.240^{* *}$ & $-.310^{* *}$ & -.023 & .049 \\
Concentration & $.422^{* *}$ & $.449^{* *}$ & 1.000 & $.262^{* *}$ & $.222^{* *}$ & $.835^{* *}$ \\
Infrastructure & $.876^{* *}$ & $-.285^{* *}$ & $.349^{* *}$ & 1.000 & $.523^{* *}$ & $.442^{* *}$ \\
Innovation & $.834^{* *}$ & $-.182^{* *}$ & $.392^{* *}$ & $.812^{* *}$ & 1.000 & $.315^{* *}$ \\
Settl. struct. & $.454^{* *}$ & .049 & $.618^{* *}$ & $.523^{* *}$ & $.466^{* *}$ & 1.000
\end{tabular}

The Pearson correlation coefficients and the Spearman rank-order correlation coefficients are shown above and below the main diagonal, respectively. ${ }^{* *}$ stands for the $1 \%$ significance level.

Since the ultimate aim of our analysis is to create homogeneous groups, the aggregate redundancy of individual layers was also examined. According to Sajtos-Mitev (2007), if the correlation between individual variables is too strong (above 0.9), their joint application leads to redundancy or distortion. Although no correlation of such strength was found, we had no information on the group of

12 The use of the latter (rank-order correlation coefficient) is important for the treatment of outlier data.

Regional Statistics, Vol 5, No 2. 2015: 34-61; DOI: 10.15196/RS05203 
variables. This is why the test/indicator expressing the suitability of the variables involved is used during the main component analysis. The KMO index has proved that the layers involved are suitable for the main component analysis, which means that redundancy exists but it has only a weak or moderate level (Sajtos-Mitev 2007, Füstös-Szalma 2009; Table 3).

In our opinion, the paired and aggregated correlations of the layers created with socio-economic content represent a versatile spatial structure and, therefore, enable us to describe the special features of the spatial structure in Central and Eastern Europe. Before that, though, we describe the spatial relations of the individual layers.

Table 3

\section{Redundancy test of spatial structure layers}

\begin{tabular}{l|l|r}
\hline \multicolumn{2}{c|}{ Kaiser-Meyer-Olkin Measure of Sampling Adequacy } & .625 \\
\hline \multirow{3}{*}{ Bartlett's test of Sphericity } & Approx. Chi-Square & $1,188.603$ \\
\cline { 2 - 3 } & $\mathrm{df}$ & 15 \\
\cline { 2 - 3 } & Sig. & .000
\end{tabular}

For this purpose, we have used bivariate global and local autocorrelation analyses. Table 4 contains Moran's I for the bivariate global autocorrelation analyses. The purpose is to identify how one phenomenon influences the spatiality of another and to see the direction and strength of the spatial configuration resulting from their interaction $^{13}$ (Anselin 2003). The layers in the first column of Table 4 represent spatially lagged variables ' $y$ ', while the layers in other columns always produce the corresponding variable ' $\mathrm{x}$ '. The first figure $(-0.297)$ expresses how the society layer influences the spatiality of the economy layer. The figure indicates negative neighbourhood assimilation for the two parameters.

Table 4

Bivariate global autocorrelation analyses of spatial structure layers (Moran's I)

\begin{tabular}{l|r|r|r|r|r}
\hline & Society & Concentration & Infrastructure & Innovation & $\begin{array}{c}\text { Settlement } \\
\text { pattern }\end{array}$ \\
\hline Economy & -.297 & .064 & .750 & .424 & .157 \\
Society & - & .214 & -0.350 & -.157 & .008 \\
Concentration & & - & .087 & .053 & .037 \\
Infrastructure & & & - & .435 & .297 \\
Innovation & & & & - & .105
\end{tabular}

The neighbourhood matrix is based on queen-1 contiguity. Pseudo-p 0.05; number of permutations: 999.

${ }^{13}$ It is answered through Moran's I. If $\mathrm{I}>-1 / \mathrm{N}-1$ then the autocorrelation is positive; if $\mathrm{I}<-1 / \mathrm{N}-1$ then it is negative. If $\mathrm{I}=-1 / \mathrm{N}-1$ then there is no autocorrelation between the individual spatial units. Its maximum approaches 1 , its minimum approaches -1 , but it has no precise value as it depends on the neighbourhood matrix and the number of spatial units (Dusek 2004). In the current case $-1 / \mathrm{N}-1=-0.003$. 
Furthermore, the network and economy layers exhibit a tight parallel movement and clustering where Moran's I equals 0.750 . Negative neighbourhood assimilation was detected in three cases, while the remaining 12 cases show some level of positive autocorrelation. ${ }^{14}$ Nevertheless, the tight correlation detected formerly between the settlement structure and concentration layers (Table 2) is lost 'in space'.

Figure 2

\section{Local spatial autocorrelation pattern of society and economy}

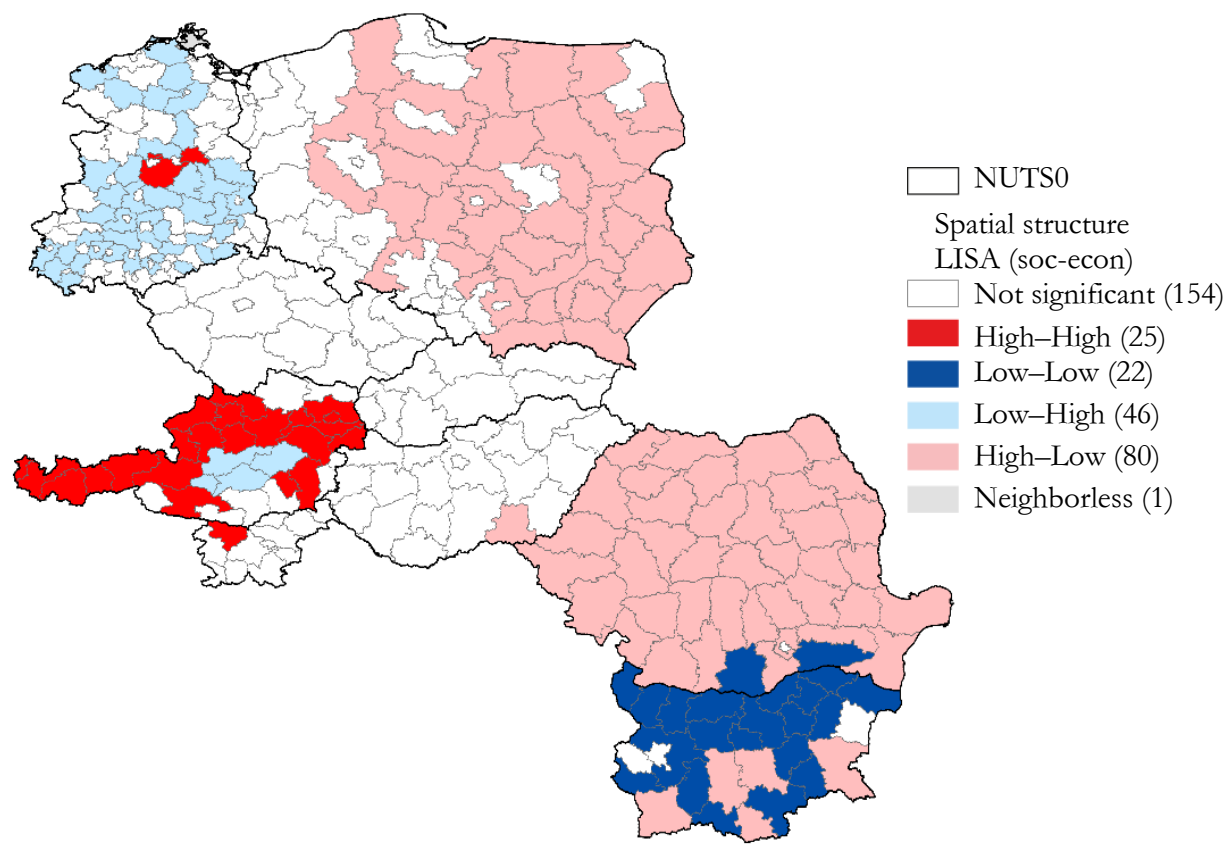

Accordingly, settlement structure does not generate any substantial spatial impact and only has an emanating impact on the individual socio-economic nodes..$^{15}$ It is (also) probable, based on this correlation, that the spatial character of the level of socio-economic development takes the shape of a 'bunch of grapes'.

The following Figures show two correlations of extreme values and describe their local pattern based on Local Moran's I. The local pattern shows the spatial arrangement (high-high, low-low) of high values (hot spot) and low values (cold spot)

\footnotetext{
${ }^{14}$ The sign and strength of the correlations are similar to those of the correlation coefficients.

${ }^{15}$ A methodological note should be made here. Both layers display a large number of outstanding values. This status is attributable to the applied indicator structure and the method of delimitation. (The impact of indicator structure is more marked in the case of the concentration layer as the use of density indicators facilitates the emergence of the above feature.) The logarithmisation of the applied indicators could have made it easier to identify spatial emanating impacts (due to the narrowing of the data series), but in this case the outstanding nature and the spatial dominance would have been eliminated for these subregions.
}

Regional Statistics, Vol 5, No 2. 2015: 34-61; DOI: 10.15196/RS05203 
and the locations of the spatial units that significantly differ from each other (low-high, high-low).

\section{Spatial configuration of network and economy layers in Central and Eastern Europe}

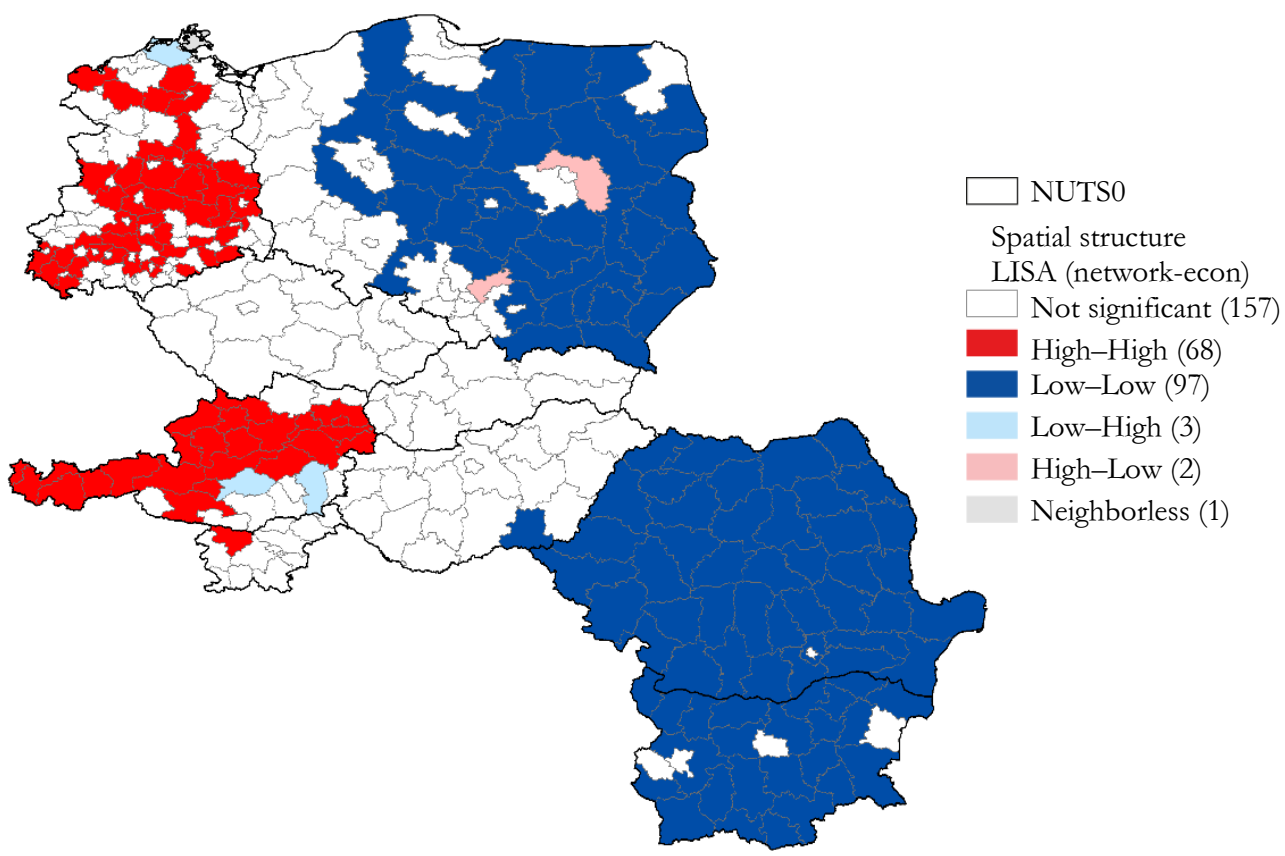

Figure 3

Although the negativity of neighbourhood assimilation is stronger between the network and society layers (Moran's $I=-0.350$ ), we describe the joint spatial configuration of the two central layers (society and economy; Figure 2). This spatial arrangement shows the one-sided status of the two basic parameters in Central and Eastern Europe; the number of outlier subregions (LH, HL) exceeds, even separately, the extent of those in the clean (HH, LL) clusters. Adverse spatial relations (low society-low economy) occur mostly in the Bulgarian region and in two Romanian (cross-border) regions. The significant arrangement of high-high is present in only 26 subregions, and only Austria displays a continuous cluster. Apart from the $\mathrm{HH}$ clusters of Berlin and Potsdam in (the former) East Germany, almost the entire country area is a spatial outlier, and the adverse society layers are coupled with a fairly strong economy layer. The high society-low economy outlier cluster is fairly extensive: apart from the central and eastern subregions of Poland, it includes Romania and some subregions of Bulgaria. An example of spatially synergistic layers is shown in Figure 3. The east-west division of the network and economy layers is clearly visible, leading to significant hot spot and cold spot clusters. The majority of 
East German and Austrian subregions is continuous HH, while LL groups exhibit a strong level of eastern determination. The number of outliers is small: only five regions 'disturb' the space of uniform clusters.

\section{Results of cluster analysis}

A cluster analysis was performed to typify the individual NUTS3 regions and to delimit the spatial units of various development stages that can be separated from each other.

At the start of the analysis, it is useful to recall that 'the term of spatial structure should be used to denote designs that demonstrate the socio-economic features of geographic space in a selective, generalised, and simplified manner' (Szabó-Farkas 2014). However, in our case, the large number of elements, the applied variables, and the issue of modifiable territorial units enabled and, moreover, forced us to display the versatile spatial structure. We have opted for the two-step cluster method because it: (i) eliminates the disadvantages of the K-means analysis suitable for handling a large number of elements (Lukovics-Kovács 2011), (ii) makes a proposal for the ideal number of clusters, and (iii) enables us to interpret groups of special characters (Sajtos-Mitev 2007). After several attempts, 21 was chosen as the number of clusters. This number was justified by the result of the Silhouette coefficient ( 0.4 means acceptable category) used for the statistical interpretation of consistency.

Table 5

General features of city and urban clusters

\begin{tabular}{l|r|r|r|r|r|r}
\hline Urban clusters & Economy & Society & $\begin{array}{c}\text { Concent- } \\
\text { ration }\end{array}$ & $\begin{array}{r}\text { Infra- } \\
\text { structure }\end{array}$ & Innovation & $\begin{array}{c}\text { Settl. } \\
\text { pattern }\end{array}$ \\
\hline Pentagon & 1.67 & 1.27 & 5.15 & 1.43 & 0.75 & 3.98 \\
$\quad$ cornerstones & 0.22 & 1.21 & 9.71 & -0.43 & -0.28 & 4.98 \\
Balkan focal point & 0.37 & 0.60 & 2.34 & 0.17 & -0.31 & 2.73 \\
Polish large centres & -0.18 & 0.80 & 0.54 & -0.05 & -0.46 & 1.09 \\
Silesian metropolis & 1.95 & 0.25 & 1.31 & 1.78 & 9.29 & 1.22 \\
'City of science' & 1.57 & 0.40 & 0.83 & 1.30 & 4.35 & 1.33 \\
German stars (1) & 1.49 & -0.99 & 0.98 & 0.81 & -0.10 & 2.25 \\
German stars (2) & 1.45 & -0.17 & 1.28 & 1.96 & 1.36 & 2.29 \\
German stars (3) & & & & & & \\
Ageing subcentres & & & & & & \\
with declining & 1.24 & -1.50 & 0.30 & 1.14 & 0.42 & 1.05 \\
population & 1.98 & 0.96 & 0.36 & 1.30 & 1.84 & 0.14 \\
Austrian regional & & & &
\end{tabular}

Regional Statistics, Vol 5, No 2. 2015: 34-61; DOI: 10.15196/RS05203 
To avoid redundancy, the spatial structure of Central and Eastern Europe will be described in three parts. First, we describe the main focal points, cities and urban areas; then their spatial expansion and relevant groups (agglomerations and wider hinterlands); finally, the scarcely populated rural-peripheral clusters. Due to the differing delimitation (often by nation) of spatial units and the absence of a settlement network layer, the results need to be adjusted. Therefore, spatial typification was compared to the population-based categorisation of functional urban regions ${ }^{16}$ (Figure 4). In view of this (and our previous knowledge), it is stated in advance that the relevant metropolis regions can be detected and delimited with a good approximation. Additional spatial structure types (e.g. agglomerations, hinterlands, and scarcely populated rural areas) can also be identified. However, the specific nature of the delimitation represents a major obstacle for large functional urban areas with more than 250,000 inhabitants.

The groups of cities and urban areas shown as major socio-economic nodes result in a versatile structure; this is reinforced by the fact that these groups account for almost half of all clusters (Table 5). The first cluster, named Pentagon comerstones, includes cities located at the top of the settlement hierarchy: Berlin, Vienna, Prague, Budapest, and Warsaw. The most important socio-economic gravity points are ranked first in almost every layer: economy, concentration, and settlement structure are outstanding, while network and society provide one of the best results in urban areas. The only factor that lags behind is innovation: it shows the east-west division within the group as Budapest, Prague, and Warsaw produce only one-sixth or one-seventh of the patent indicators shown for Vienna and Berlin. Bucharest is the sole member of the cluster named Balkan focal point. Its socio-economic concentration, just like its settlement structure layer, is the highest in the region under review. Its economic dimension is significantly below the average, but this is true only for the static indicators. In fact, it has outstanding economic dynamics, the highest among the studied capital cities. The population retention layer is similarly positive in the capital city of Romania, although lags in the fields of infrastructure and innovation make Bucharest a one-sided urban pole. The next two clusters show national nature. The Polish large centres such as Lodz, Cracow, Katowice, Poznan, Wroclaw, and the Tri-City (Gdansk-Sopot-Gdynia) emerge as substantial socio-economic gravity points in the Central and Eastern European space under review. Despite their large populations - indicated also by the outstanding values of the concentration and settlement

${ }^{16}$ The urban function study of ESPON (2007) was used for this issue. In that study, the large functional urban areas (FUAs) are regions with 250,000-500,000 inhabitants and the metropolis areas are regions with more than 500,000 inhabitants. Besides population numbers, the national and international decision-making centres, transport infrastructure, knowledge, culture, tourism, and industrial output play a role in the determination of FUAs (ESPON 2005, 2007).

Regional Statistics, Vol 5, No 2. 2015: 34-61; DOI: 10.15196/RS05203 
structure layers - they perform poorly in terms of innovation and infrastructure, in comparison with other metropolis regions, and thus diminish their existing advantages. The Silesian metropolis covers most of the macroregion termed the 'black hole' by Gorzelak (1997). This cluster embodies the multi-centre agglomeration of Katowice, except for Moravia (Moravskoslezský kraj) in the Czech Republic. The Sofia region also joins the agglomeration, which is facilitated by similar settlement structure factors and the delimitation effort. Population retention is above the average in both clusters.

The next six clusters are located on the western side of the region under review, i.e. in (the former) East Germany and Austria. The cluster named City of science has only one member. The city of Jena represents the highest innovation potential in the region, coupled with a fairly strong economic position. Its role of socio-economic gravity point weakens in terms of population retention; ageing is a particular challenge for the city. The German stars cover German regions and the subregions of Graz and Bregenz. Their rank is based on economic output. The group of German stars (1) covers large centres and metropolises (Dresden and Graz) but also includes smaller regional urban areas of innovation and tourism (e.g. Potsdam, Greifswald, Ilm-Kreis, and Bregenz). Of the three clusters, this one has the strongest innovation layer, supported also by its excellent network and economy layers. The centre of German stars (2) is the metropolis area of Chemnitz-Zwickau and the regional service centres of Magdeburg, Rostock, and Cottbus. Their strong economic potential is coupled with poor innovation, and this status is further weakened by the society layer. This cluster is burdened with one of the highest rates of ageing, emigration, and unemployment. Concentrated in space, the cluster named German stars (3) is located in the south-western part of (the former) East Germany. Its central region is the Lepzig-Halle metropolis accompanied by Weimar and Erfurt. Its spatial structure layers are above the average in most cases. In particular, the network layer is outstanding (due to its great accessibility by rail and road). However, the society layer is not so impressive. The common feature of the cluster named Ageing subcentres with declining population (Frankfurt, Schwerin, Görltiz, Gera, etc.) is the low population level $(40,000-130,000$ inhabitants). The population retention layer is substantially below the average, compromising the better economy and infrastructure layers.

Regional Statistics, Vol 5, No 2. 2015: 34-61; DOI: 10.15196/RS05203 


\section{Spatial structure of Central and Eastern Europe shown on the basis of socio-economic layers}

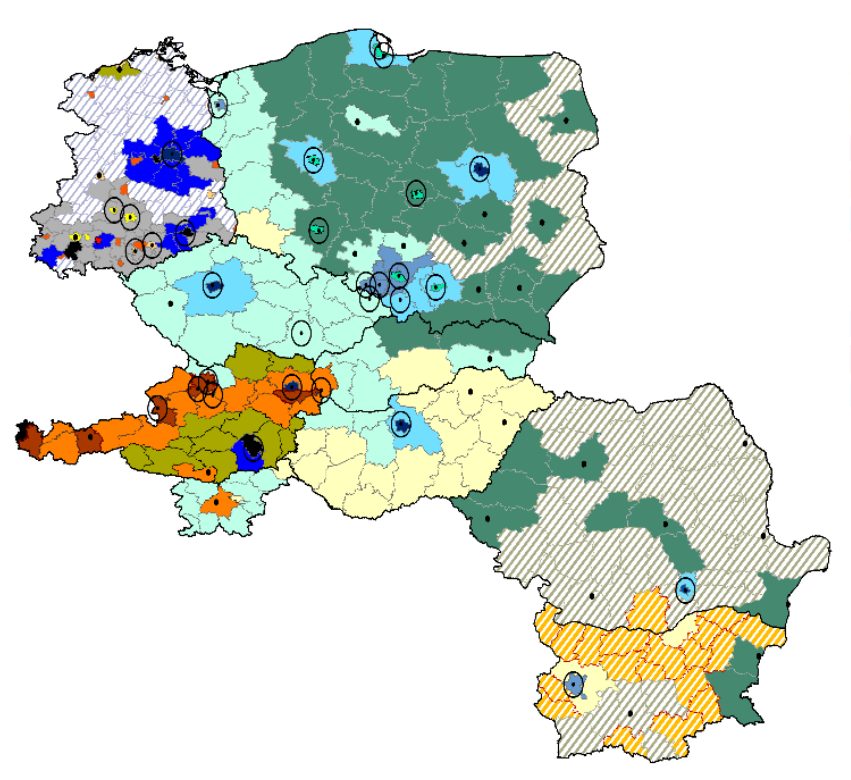

- Large FUA

(- Metropolis FUA

Figure 4

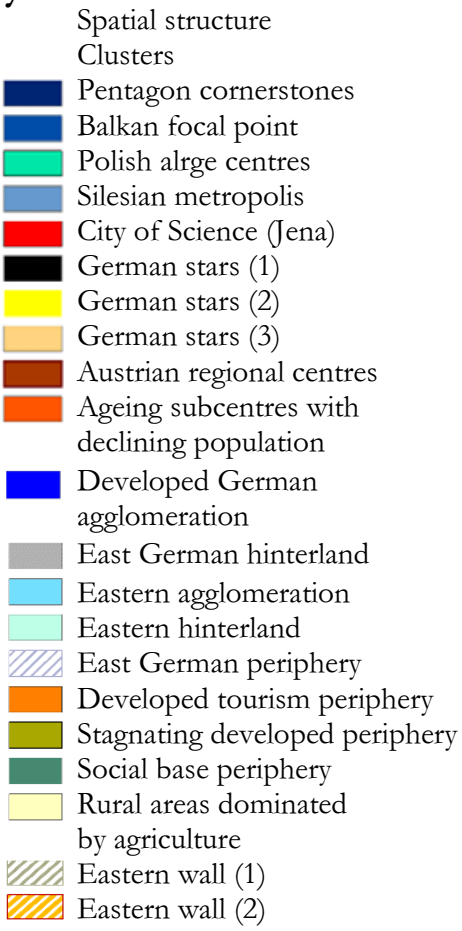

The Austrian regional centres represent the tertiary nodes of Austria (e.g. cross-border functional uban area of Salzburg, metropolis region of Linz-Wels, Innsbruck, etc.) or belong to such nodes (e.g. the southern agglomeration of Vienna). It is characterised with the most balanced layer structures; lagging in the case of concentration and settlement structure layers is attributable only to the delimitation effort.

Table 6

\section{Average output of layers in the attraction zone regions}

\begin{tabular}{l|c|c|c|c|c|c}
\hline \multicolumn{1}{c|}{ Emanating clusters } & Economy & Society & $\begin{array}{c}\text { Concent- } \\
\text { ration }\end{array}$ & $\begin{array}{c}\text { Infra- } \\
\text { structure }\end{array}$ & $\begin{array}{c}\text { Inno- } \\
\text { vation }\end{array}$ & $\begin{array}{c}\text { Settl. } \\
\text { pattern }\end{array}$ \\
\hline Developed German & 0.69 & -0.42 & -0.29 & 1.02 & 1.36 & 0.12 \\
$\quad$ agglomerations & 0.60 & -1.35 & -0.31 & 1.13 & -0.01 & 0.11 \\
East German hinterland & -0.58 & 1.72 & -0.09 & 0.02 & -0.40 & 0.18 \\
Eastern agglomeration & -0.04 & 0.73 & -0.09 & 0.02 & -0.34 & -0.32 \\
Eastern hinterland & & & & &
\end{tabular}


The attraction zones are categorised along two distance dimensions: the ones closer to cities are called agglomerations and the larger ones located further away from cities are named hinterlands (Table 6). These attraction zones are divided in space as well. The differences come from the interaction between the layers. The east-west differences should be interpreted in terms of the economy, society, infrastructure, and innovation layers. The developed East German agglomerations refer to the attraction zones of Berlin, Dresden, Jena, Erfurt, and Graz. The economy, network, and innovation layers of the regions reinforce each other, but the society layer represents a strong deteriorating factor. However, the Eastern agglomerations excel in the field of population retention, while their other layers fail to reach the average of the region under review. The Eastern agglomerations represent the emanating impacts of such regional nodes and the Tri-City, Warsaw, Prague, Budapest, Bucharest, Cracow, Katowice, and Poznan. The East German binterland and the Eastern binterland cover an extensive zone of loose settlement structure beyond the agglomerating regions. Concentrated in the southern part of (the former) East Germany, the East German hinterland provides a background for agglomerations and metropolis FUAs. Moreover, the Eastern regions with an expanded attraction zone function as connection axes towards the West: Poland has a belt area along the German border, while the entire area of the Czech Republic, the western layers of Slovakia and Hungary, and the Slovenian layers of good network properties help the formation of these spaces. This spatial character facilitates the acceptance of the new banana structure.

The East German periphery is one of the most backward clusters in terms of the population layer; it is above the average economy and network layers are unable to improve the poor state of ageing, emigration, and unemployment. The categories of developed tourism periphery and stagnating developed periphery are present mainly in Austria. Among the rural areas, the innovation layer is outstandingly reinforced - for the developed tourism peripherycluster type - by the economy, society, and network layers. This category is characterised by a high capacity for tourism. The subregions of Bratislava and Ljubljana are also part of the region; the awkward position is attributable partly to the delimitation effort. ${ }^{17}$ Although the level of concentration differs from that of other Austrian regions, the innovation, infrastructure, and society layers direct them into the same cluster. The units of stagnating developed periphery are found in Austria; their economic, network, and innovation potential exceeds that of similar cluster groups located in the east. The clusters named social base periphery and rural areas dominated by agriculture are similar, but the former has a vigorous population retention layer and the latter has a satisfactory economy layer. The remaining layers are significantly below the average. The peripheral regions are concentrated into two clusters named 'eastern wall (1)' and 'eastern wall (2)'. These groups suffer from

\footnotetext{
${ }^{17}$ Both capital cities were considered with their respective attraction zones. Their respective population figures are not outstanding as these subregions have some 500,000 inhabitants.
}

Regional Statistics, Vol 5, No 2. 2015: 34-61; DOI: 10.15196/RS05203 
multidimensional backlogs in terms of the economy, infrastructure, and innovation layers, which are the worst among the studied regions. The relatively more developed first group - encompassing Polish eastern subregions as well as Romanian and Bulgarian subregions - has a much stronger society layer, exceeding even that of rural areas dominated by agriculture (which comprise mostly Hungarian regions). The second category accommodates the least developed Romanian and Bulgarian regions, but the society layer does not exceed the average of the East German periphery (Table 7).

Layer characteristics of rural and peripheral clusters

\begin{tabular}{l|c|c|c|c|c|c}
\hline \multicolumn{1}{c|}{ Emanating clusters } & Economy & Society & $\begin{array}{c}\text { Concent- } \\
\text { ration }\end{array}$ & $\begin{array}{c}\text { Infra- } \\
\text { structure }\end{array}$ & $\begin{array}{c}\text { Inno- } \\
\text { vation }\end{array}$ & $\begin{array}{c}\text { Settl. } \\
\text { pattern }\end{array}$ \\
\hline $\begin{array}{l}\text { East German periphery } \\
\begin{array}{l}\text { Developed tourism } \\
\text { periphery }\end{array}\end{array}$ & 0.60 & -1.45 & -0.49 & 0.58 & -0.25 & -0.67 \\
$\begin{array}{l}\text { Stagnating developed } \\
\text { periphery }\end{array}$ & 0.69 & 0.00 & -0.31 & 0.13 & 0.32 & -0.56 \\
Social base periphery & -0.83 & 0.83 & -0.21 & -0.79 & -0.47 & -0.47 \\
Rural areas dominated & & & & & & \\
$\quad$ by agriculture & -0.47 & -0.18 & -0.33 & -0.68 & -0.42 & -0.49 \\
Eastern wall (1) & -1.40 & 0.44 & -0.38 & -1.38 & -0.50 & -0.43 \\
Eastern wall (2) & -1.26 & -0.84 & -0.45 & -1.38 & -0.50 & -0.69
\end{tabular}

Several large FUAs are found in the area covered by clusters named social base periphery and rural areas dominated by agriculture: on the eastern side of Poland, in the relatively more developed subregions of Romania, in the seaside regions of Bulgaria, and in Eastern Hungary. It is also evident that these smaller poles of regional level are unable to properly highlight their regional base from the rural space or to ascend to a higher category from the deep peripheries (e.g. see the cases of Bialystok, Lublin, Kielce, Brasov, Cluj Napoca, Constanta, and Varna). However, Iasi, Craiova, Galati, and Plovdiv are unable to make such upward progress due to their low socioeconomic weight in the periphery of Central and Eastern Europe and to their (current) inability to improve their state of backwardness.

\section{Summary}

Our study aimed to demonstrate the spatial structure of Central and Eastern Europe. For this purpose, we employed and operationalised the spatial structure and then described the territorial characteristics of the region with the use of multivariate and spatial methods.

According to the results obtained, the main socio-economic processes are deemed suitable for modelling by layer and the model is deemed suitable for use in spatial 
structure research work. The layers represent rather fragmented areas characterised by traditional differences (east-west, urban-rural) and other (nationwide) inequalities. The layers have versatile correlations and both synergistic and antagonistic mechanisms. In particular, the two most important layers (economy and society) do not show coherent parallel movements, which indicates serious problems in terms of future demographic processes. By employing the multivariate methodology, the relevant layers lead to a versatile spatial structure. As a result, it is difficult to perform the usual and straightforward categorisation using generalised figures. Therefore, we describe the main elements in three parts: cities/urban areas generating development, attraction zone regions, and rural/peripheral clusters. At the same time, our results also highlight the main transformation processes (demographics, innovation, and urbanisation) affecting the region. According to our analyses, developed areas that are either banana-shaped or shaped like a bunch of grapes (polycentric) can be found in the region. In the former case, the new banana shape seems to have a more solid base, and the mathematical-statistical methods have also identified a string of the western subregions of the Visegrád countries. However, the eastern wall covers a much larger area than in the former figures.

Since our study aimed to typify intermediate regions, i.e. areas considered peripheral from a European perspective (except for Austria), the study results should be interpreted within that framework. Although our study was intended to serve the purpose of identification and analysis, it may be used as a point of reference for the development aspects of European (cross-border, transnational, and inter-regional) territorial cooperation initiatives affecting the macroregions.

\section{REFERENCES}

ANSELIN, L. (2003): An Introduction to Spatial Autocorrelation Analysis with GeoDa Spatial Analysis Laboratory Department of Agricultural and Consumer Economics, University of Illinois, Urbana-Champaign.

ANSELIN, L. (2005): Exploring Spatial Data with GeoDaTM: A Workbook Center for Spatially Integrated Social Science, Spatial Analysis Laboratory Department of Geography University of Illinois, Urbana-Champaign.

BAjMÓCY, Z. - SZAKÁLNÉ KANÓ, I. (2009): Hazai kistérségek innovációs képességének elemzése Tér és Társadalom 23 (2): 45-68.

BRUNET, R. (1989): Les villes europeénnes: Rapport pour la DATAR Reclus, Montpellier.

CsÉfalvay, Z. (1999): Helyünk a nap alatt... Magyarország és Budapest a globalizáció korában Kairosz Kiadó/Növekedéskutató, Győr.

EC (1999): European Spatial Development Perspective. Towards Balanced and Sustainable

Development of the Territory of the European Union Office for Official Publications of the European Communities, Luxembourg.

DijKSTRA, L. (2009): Metropolitan regions in the EU Regional Focus nr. 01/2009.

Regional Statistics, Vol 5, No 2. 2015: 34-61; DOI: 10.15196/RS05203 
Dommergues, P. (1992): The Strategies for International and Interregional Cooperation Ekistics 59:352/353.

DusEK, T. (2004): A területi elemzések alapjai Regionális Tudományi Tanulmányok 10., ELTE TTK Regionális Földrajzi Tanszék, Budapest.

DusEK, T. - KISS, J. P. (2008): A regionális GDP értelmezésének és használatának problémái Területi Statisztika 48 (3): 264-280.

EC (2008): Green Paper on Territorial Cohesion. Turning territorial diversity into strength Communication from the Commission to the Council, the European Parliament, the Committee of the Regions and the European Economic and Social Committee, Brussel.

EC (2010): Rural Development in the European Union Statistical and Economic Information Report 2010. Directorate-General for Agriculture and Rural Development, Brussel.

EC (2011): Territorial Agenda of the European Union 2020. Towards an Inclusive, Smart, and Sustainable Europe of Diverse Regions http://www.terport.hu/webfm_send/2291 (Downloaded: 12.10.2012).

Dijkstra, L. - Poelman, H. (2011): Regional typologies: a compilation Regional Focus nr. $01 / 2011$.

EC (2014): Population ageing in Europe Facts, implications and policies Directorate-General for Research and Innovation, Brussel.

EgRI, Z. - LiTAusZKY, B. (2012): Térszerkęeti sajátosságok Közép-Kelet-Európában http://www.mrtt.hu/vandorgyulesek/2012/2/egri.ppt (Downloaded: 20.11.2015).

ESPON (2005): Potentials for polycentric development in Europe ESPON 1.1.1. Project. ESPON Coordination Unit, Luxembourg.

ESPON (2006): Urban-rural relations in Europe. ESPON 1.1.2. Final Report. ESPON Coordination Unit, Luxembourg.

ESPON (2007a): ESPON project 4.1.3 Feasibility study on monitoring territorial development based on ESPON key indicators ESPON Coordination Unit, Luxembourg.

ESPON (2007b): Study on Urban Functions ESPON 1.4.3 Final Report, ESPON Coordinate Unit, Luxembourg.

ESPON (2010): Metropolitan macroregions in Europe: from economic landscapes to metropolitan networks (Cities and their Hinterlands) FOCI Future Orientations for Cities Final Scientific Report, ESPON Coordinate Unit, Luxembourg.

ESPON (2012a): EDORA European Development Opportunities for Rural Areas Final Report, ESPON Coordination Unit, Luxembourg.

ESPON (2012b): SGPTD Second Tier Cities and Territorial Development in Europe: Performance, Policies and Prospects Final Report, ESPON Coordination Unit, Luxembourg.

ESPON (2014): ET2050 Territorial Scenarios and Visions for Europe Final Report, ESPON Coordination Unit, Luxembourg.

FÜSTÖS, L. (2009): A sokváltozós adatelemzés módszerei In.: Füstös L. - Szalma I. (ed.): Módszertani füzetek 2009/1. MTA Szociológiai Kutatóintézete Társadalomtudományi Elemzések Akadémiai Mühelye (TEAM), Budapest.

GorzelaK, G. (1997): Regional Development and Planning in East Central Europe In: Keune, M. (Ed.): Regional Development and Employment Policy: Lessons from Central and Eastern Europe pp. 62-76., ILO, Budapest.

Regional Statistics, Vol 5, No 2. 2015: 34-61; DOI: 10.15196/RS05203 
GorZELAK, G. (2001): Regional Development in Central Europe and European Integration Informationen zur Raumentwicklung Heft (11/12): 743-749.

GorzelaK, G. (2006): Main Processes of Regional Development in Central and Eastern Europe after 1990. Regional Diversity and Local Development in Central and Eastern Europe Conference paper. http://www.oecd.org/dataoecd/58/41/37778478.pdf (Downloaded: 20.11. 2015).

HALL, P. (1992): Urban and Regional planning Routledge, London.

Horváth, Gy. (2013): A német Mezzogiorno? A keletnémet regionális fejlődés az újraegyesítés után Területi Statisztika 53: (5) 492-514.

KINCSES, Á. - NAGY, Z. - TóTH, G. (2013a): Európa térszerkezete különböző matematikai modellek tükrében, I. rész Területi Statisztika 53 (2): 148-156.

KINCSES, Á. - NAGY, Z. - TÓTH, G. (2013b): Európa térszerkezete különböző matematikai modellek tükrében, II. rész Területi Statisztika 53 (3): 237-252.

KunZmann, K. R. - WegEnER, M. (1991): The pattern of Urbanization in Western Europe Ekistics 58: 350-351.

Leibenath, M. - Hahn, A. - KNippschild, R. (2007): Der „Mitteleuropäische Kristall“ zwischen „Blauer Banane“ und „osteuropäischem Pentagon“. Perspektiven der neuen zwischenstaatlichen deutsch-tschechischen Arbeitsgruppe für Raumentwicklung Angewandte Geographie 31 (1): 36-40.

Lengyel, I. - ReChnitzer, J. (2004): Regionális gazdaságtan Dialóg Campus Kiadó, BudapestPécs.

LENGYEL, I. (2012): Regionális növekedés, fejlődés, területi tőke és versenyképesség In.: BAjMÓCY, Z. - LENGYel, I. - MÁLOVICS, GY. (ed.): Regionális innovációs képesség, versenyképesség és fenntarthatóság pp. 151-174., JATEPress, Szeged.

LENGYEL, I. (2003): Verseny és terïleti fejlödés: térségek versenyképessége Magyarországon JATEPress, Szeged.

LukOVICS, M. - KovÁCS, P. (2011): A magyar kistérségek versenyképessége Területi Statiştika 51 (1): 52-71.

Lux, G. (2012): A gazdaság szerepe a városi térségek fejlesztésében: A globális kihívásoktól a fejlesztéspolitikáig In.: SOMLYÓDYNÉ PFEIL, E. (ed.): Az agglomerációk intézményesitésének sajátos kérdései: Három magyar nagyvárosi térség az átalakuló térben pp. 67-89., Publikon Kiadó, Pécs.

Nemes Nagy, J. - TAGAI, G. (2009): Területi egyenlőtlenségek, térszerkezeti determinációk Területi Statisztika 49 (2): 152-169.

OECD (2011): Invention and Transfer of Environmental Technologies OECD Studies on Environmental Innovation, OECD Publishing, Washington.

OECD (2013): Regions and Innovation: Collaborating across Borders OECD Reviews of Regional Innovation, OECD Publishing, Washington.

Paqué, K-H. (2009): The Transformation Policy in East Germany - A Partial Success Story http://www.kas.de/upload/Publikationen/Panorama/2009/1/paque.pdf (Downloaded: 15.11.2014).

PorTer, M. E. - STERn, S. (2001): National Innovative Capacity Oxford University Press, New York.

Regional Statistics, Vol 5, No 2. 2015: 34-61; DOI: 10.15196/RS05203 
Rechnitzer, J. - Grosz, A. - HArdi, T. - Kundi, V. - SurÁnYI, J. - SzÖrÉnYiné KUKORELLI, I. (2008): A magyarországi Felsö-Duna szakasz fejlesztési kérdései MTA RKK NYUTI, Győr.

RECHNITZER, J. - SMAHÓ, M. (2011): Területi politika Akadémiai Kiadó, Budapest.

RECHNitzer, J. (2013): Adalékok Kelet-Közép-Európa térszerkezetének felrajzolására Geopolitika a XXI. században 3 (4): 35-52.

SAjTos, L. - Mitev, A. (2007): SPSS kutatási és adatelemzési kézikönyv Alinea Kiadó, Budapest.

SIC! (2006): Sustrain implement corridor. Long factbook.

http://195.230.172.167/cms_sic/upload/pdf/061010_SIC_LongFactbook.pdf

(Downloaded: 12.10.2012).

Simai, M. (2014): A térszerkezet és a geoökonómia Tér és Társadalom 28 (1): 25-39.

SMAHÓ, M. (2011): A tudás és a regionális fejlōdés összefüggései Doktori értekezés. Széchenyi István Egyetem Multidiszciplináris Társadalomtudományi Doktori Iskola, Győr.

SzABÓ, P. - FARKAS, M. (2014): Kelet-Közép-Európa térszerkezeti képe Tér és Társadalom 28 (2): 67-86.

SZABÓ, P. (2009): Európa térszerkezet különböző szemléletek tükrében Földrajzi Közlemények 133 (2): 121-134.

Stimson, R. - StOUgh, R. R. - NiJKAMP, P. (2011): Endogenous regional development Edward Elgar, Cheltenham.

TótH, G. (2013): Bevezetés a területi elemzések módszertanába Miskolci Egyetem, Miskolc.

TÓTH, SZ. (2003): A régiók Európája Korunk 14 (1): 97-106.

VAn Der Meer, L. (1998): The Red Octopus In: BlaAs, W. (ed.) A new perspective for European spatial development policies pp. 9-26., Avebury, Aldershot.

VARGA, A. (2009): Térszerkezet és gazdasági növekedés Akadémiai Kiadó, Budapest. 


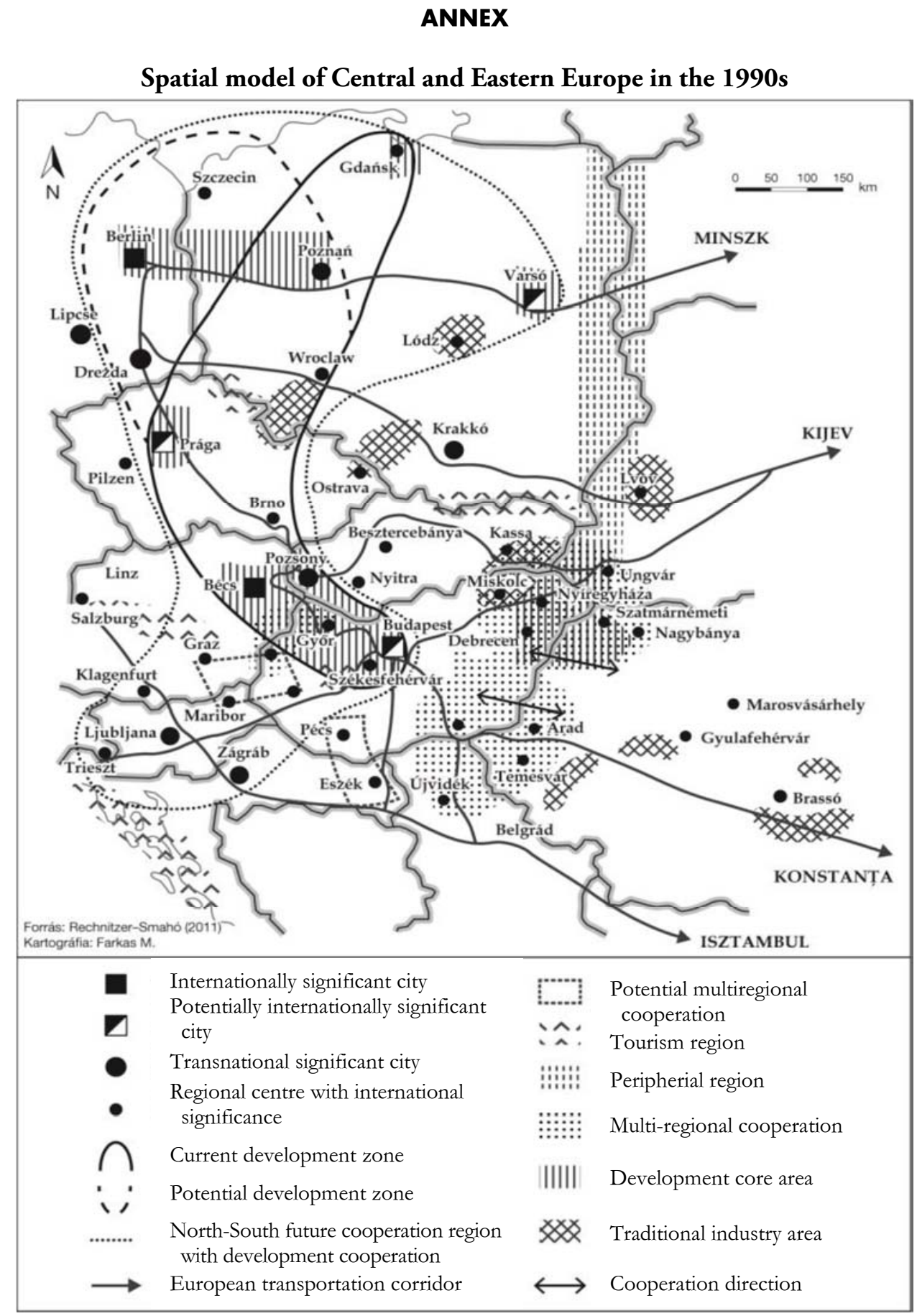

Source: Szabó-Farkas (2014) based on Rechnitzer-Smahó (2011).

Regional Statistics, Vol 5, No 2. 2015: 34-61; DOI: 10.15196/RS05203 


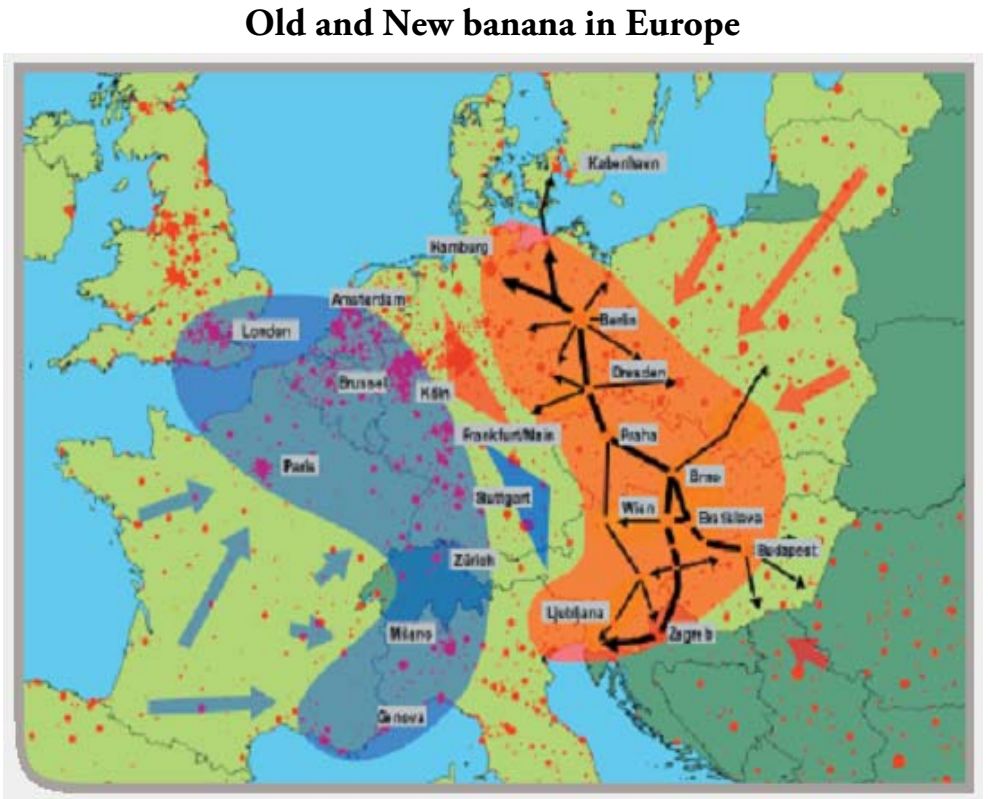

Source: SIC! (2006) 


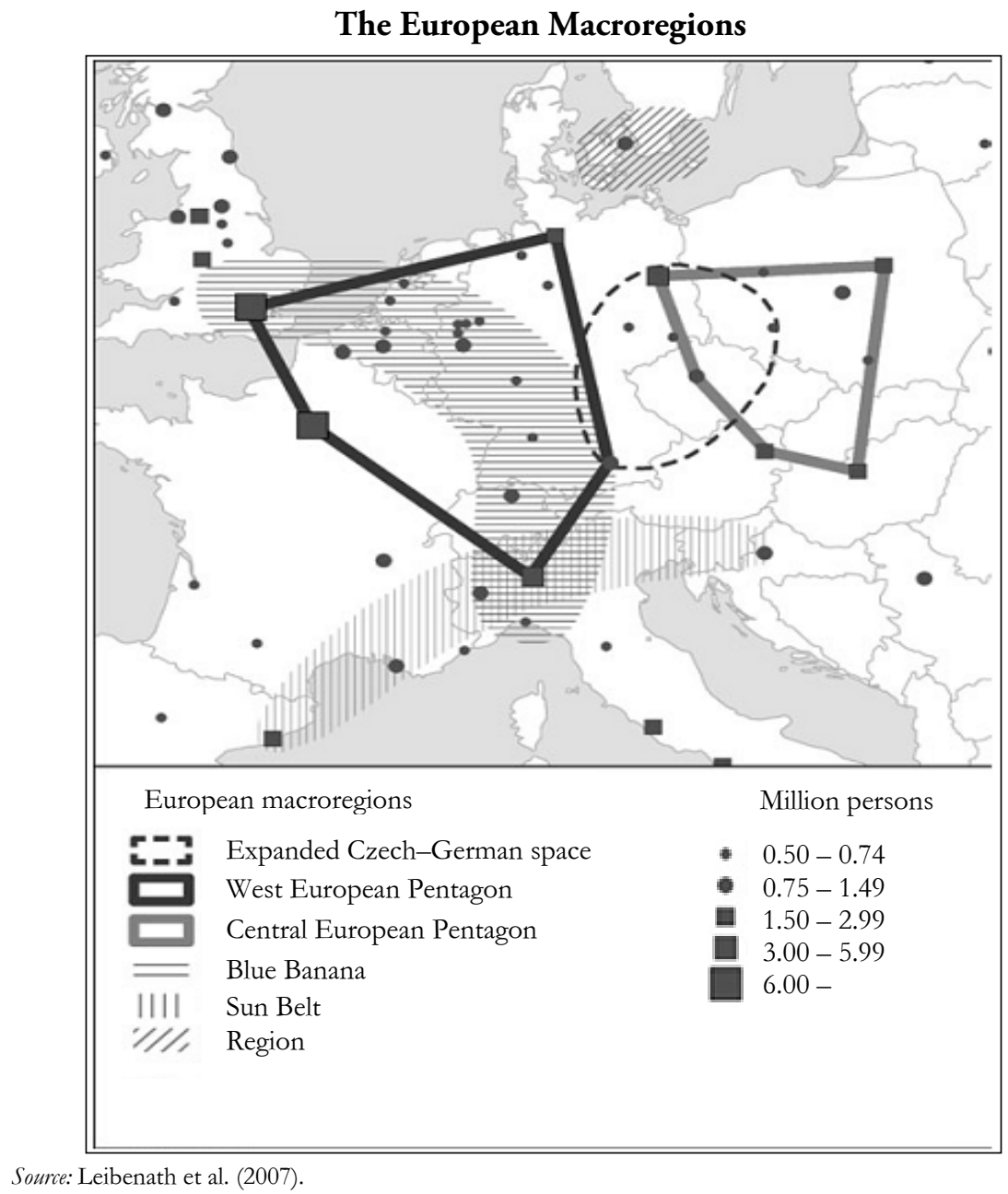

Regional Statistics, Vol 5, No 2. 2015: 34-61; DOI: 10.15196/RS05203 